\title{
DAMPAK PENGHARGAAN DALAM PEMBELAJARAN IPS DI KELAS V MADRASAH IBTIDAIYAH NEGERI
}

\author{
Iza Syahroni \\ e-mail: izasyahroni96@gmail.com \\ Magister Psikologi Pendidikan Islam \\ Universitas Islam Negeri Sunan Kalijaga Yogyakarta \\ Jalan Laksda Adisucipto, Papringan, Caturtunggal, Kec. Depok, Kabupaten Sleman, Daerah Istimewa \\ Yogyakarta 55281
}

\begin{abstract}
Abstrak: Tercapainya tujuan pembelajaran tidak terlepas dari kreativitas guru dalam proses pembelajaran, salah satu dari kreativitas tersebut adalah dengan guru memberikan penghargaan. Pemberian penghargaan atau reward kepada siswa merupakan sesuatu hal yang penting karena dapat membangkitkan atau mengembangkan minat siswa. Pemberian penghargaan memberikan dampak pada proses pembelajaran terutama pada masa anak-anak yang sedang duduk di bangku sekolah dasar seperti siswa merasa senang dan mereka akan bangga dengan apa yang sudah dikerjakan. Dengan adanya rasa seperti ini maka siswa akan termotivasi untuk mengembangkan minatnya. Penelitian ini bertujuan untuk mengetahui bagaimana dampak pemberian penghargaan dalam proses pembelajaran IPS siswa kelas V MI Negeri di Lombok Barat. Dengan menggunakan penelitian kualitatif deskriptif. Sumber data terdiri dari guru mata pelajaran IPS dan siswa kelas V Madrasah Ibtidaiyah Negeri I Lombok Barat. Teknik pengumpulan data yang digunakan adalah observasi, wawancara dan dokumentasi. Hasil penelitian ditemukan bahwa, dampak pemberian penghargaan dalam proses pembelajaran IPS adalah meningkatnya perhatian siswa dalam proses pembelajaran, meningkatkan antusias belajar siswa, meningkatnya keaktifan siswa dalam proses pembelajaran, siswa lebih bisa dikendalikan tingkah lakunya ketika proses pembelajaran berlangsung.
\end{abstract}

Kata-kata Kunci: pembelajaran, pelajaran ips, penghargaan

\section{THE IMPACT OF REWARDS IN LEARNING OF SOCIAL SCIENCES IN CLASS V PUBLIC ISLAMIC PRIMARY SCHOOL}

\begin{abstract}
Achieving learning objectives is inseparable from the creativity of teachers in the learning process, one of the creativity is giving rewards by teachers. Awarding or rewarding students is important because it can awaken or develop students' interest. Reward giving has an impact on the learning process, especially for elementary school children because the reward will make theem feeling happy and proud of what has been done. This study aims to find out how the impact of rewarding in the learning process of IPS subject for class V students of MI Negeri 1 Lobar using descriptive qualitative research. Data source consists of subject teachers and students of class V MI Negeri I Lobar. Data collection techniques used are observation, interview and documentation. The results of the study conclude that rewarding impacts learning process such as increasing attention, enthusiasm, participation of students and were more able to control their behavior during the learning process.
\end{abstract}

Keywords: learning, reward, social science 


\section{PENDAHULUAN}

Pada dasarnya manusia senantiasa membutuhkan pendidikan di dalam hidupnya. Pendidikan merupakan tujuan hidup yang harus ditempuh dengan perjuangan yang tidak mudah, karena membutuhkan pengorbanan yang tidak murah. Setiap pendidikan yang ditempuh seseorang, dipastikan akan dapat memberikan sebuah kehidupan yang berharga di masa depan (Febianti, 2018). Fungsi dari pendidikan adalah memanusiakan manusia, mengembangkan potensi agar menjadi pribadi yang memiliki kekuatan spiritual keagamaan, pengendalian diri, kepribadian, kecerdasan, akhlak mulia, serta keterampilan yang diperlukan dirinya, masyarakat, bangsa, dan Negara (Huliyah, 2016). Pendidikan merupakan sesuatu yang penting bagi negara, pentingnya pendidikan ini seperti yang tercantum dalam UU Nomor 20 Tahun 2003 tentang Sistem Pendidikan Nasional dimana pendidikan dapat dilakukan dengan belajar dan pembelajaran. Belajar dapat dilakukan sendiri oleh siswa, bisa dilakukan di sekolah ataupun di rumah. Sedangkan pembelajaran dapat dilakukan bersama-sama antara seorang guru dengan siswanya di kelas. Di dalam pembelajaran terdapat pembelajaran ilmu pengetahuan sosial sekolah dasar, ilmu pengetahuan sosial yang sering disingkat dengan IPS, hakikat IPS adalah untuk mengembangkan konsep pemikiran yang berdasarkan realita kondisi sosial yang ada di lingkungan siswa, sehingga dengan memberikan pendidikan IPS diharapkan dapat melahirkan warga negara yang bertanggung jawab terhadap bangsa dan negaranya.

Tujuan utama pembelajaran IPS ialah untuk mengembangkan potensi peserta didik agar peka terhadap masalah sosial yang terjadi di masyarakat, memiliki sikap mental positif terhadap masalah sosial yang terjadi di masyarakat, memiliki sikap mental positif terhadap perbaikan segala ketimpangan yang terjadi sehari-hari baik yang menimpa dirinya sendiri maupun yang menimpa masyarakat. Tercapainya tujuan pembelajaran tidak terlepas dari kreativitas guru dalam proses pembelajaran, yang perlu dilakukan guru adalah salah satunya dengan memberikan penghargaan bagi siswa. Siswa yang diberikan penghargaan adalah siswa yang berprestasi maupun siswa yang tidak berprestasi namun penghargaan yang diberikan perlu dibedakan. Pemberian penghargaan dapat membangkitkan minat anak untuk mempelajari atau mengerjakan sesuatu. Tujuan pemberian penghargaan adalah membangkitkan atau mengembangkan minat. Jadi, penghargaan berperan untuk membuat pendahuluan saja. Penghargaan adalah alat, bukan tujuan. Hendaknya diperhatikan jangan sampai penghargaan ini menjadi tujuan. Menurut Hamalik (2012), tujuan pemberian penghargaan dalam belajar adalah bahwa setelah seseorang menerima penghargaan karena telah melakukan kegiatan belajar dengan baik, ia akan terus melakukan kegiatan belajarnya sendiri di luar kelas.

Dari pemaparan di atas, dapat dipahami pentingnya pemberian penghargaan atau penghargaan kepada siswa. Dengan adanya pemberian penghargaan maka akan berdampak pada proses pembelajaran. Akan tetapi pada kenyataannya, kondisi yang ideal dalam proses pembelajaran dengan keadaan nyatanya di lapangan masih bisa dikatakan belum sesuai, yakni masih kurangnya pemberian penghargaan kepada siswa.

Salah satu alasan guru kurang memberikan penghargaan kepada siswanya adalah karena karena ketika proses pembelajaran guru sibuk dalam menyampaikan materi pembelajaran sehingga pemberian penghargaan kepada siswa sering terabaikan. Masa anak-anak siswa sekolah dasar sangat membutuhkan penghargaan atau penghargaan, karena pada masa itu hanya diberikan penghargaan saja mereka akan merasa senang. Bentuk penghargaan yang diberikan bisa hanya berupa pujian, apalagi penghargaan itu diberikan di tempat orang banyak, anak-anak pasti akan merasa senang dan mereka akan bangga dengan apa yang sudah dikerjakan. Seorang anak yang sedang belajar bernyanyi akan terus belajar bernyanyi dan cepat pandai bernyanyi, apabila orang tuanya memuji dan menghargainya. Dalam hal ini, motif belajar bernyanyi anak itu diperkuat dengan ganjaran yang berupa pujian atau penghargaan (Susanto, 2014).

Proses pembelajaran di Madrasah Ibtidaiyah Negeri (MIN) 1 Lombok Barat (Lobar), dilakukan dengan memberikan penghargaan untuk memotivasi siswa. Dari hasil observasi awal yang dilakukan, peneliti melihat adanya pemberian penghargaan yang dilakukan oleh guru dalam proses pembelajaran IPS pada siswa kelas V MIN 1 Lobar. Siswa diberikan penghargaan berupa pujian, acungan jempol, dan tepuk tangan. Hal ini dilakukan untuk mencegah rasa jenuh ataupun bosan dari siswa dalam proses pembelajaran khususnya pada mata pelajaran IPS yang terkesan membosankan terutama pada materi yang membahas tentang sejarah. Dengan adanya pemberian penghargaan yang dilakukan oleh guru pada siswa akan berdampak pada antusias dan semangat belajar siswa di dalam proses pembelajaran. Penelitian ini berangkat dari pertanyaan penelitian, "bagaimana penerapan penghargaan dalam mata pelajaran IPS di Kelas V MIN 1 Lobar?" 


\section{METODE PENELITIAN}

Penelitian dilakukan di MIN 1 Lobar Kecamatan Lingsar Kabupaten Lombok Barat. Dengan menggunakan penelitian deskriptif kualitatif (Danim, 2002), yaitu data yang dikumpulkan berupa kata-kata, gambar, bukan dalam bentuk angkaangka. Untuk menghasilkan data terkait, sumber data yang digunakan dalam penelitian ini adalah guru mata pelajaran IPS dan siswa kelas V MIN I Lobar. Pengumpulan data menggunakan dengan teknik observasi, wawancara, dan dokumentasi.

Tabel 1.

Kisi-kisi dan Item Pertanyaan Wawancara

\begin{tabular}{|c|c|c|}
\hline Indikator & $\begin{array}{c}\text { Pertanyaan untuk } \\
\text { Guru }\end{array}$ & $\begin{array}{c}\text { Pertanyaan untuk } \\
\text { Siswa }\end{array}$ \\
\hline \multirow[t]{2}{*}{$\begin{array}{l}\text { Bentuk } \\
\text { Penghargaan }\end{array}$} & $\begin{array}{l}\text { Ada berapa } \\
\text { macam bentuk } \\
\text { penghargaan yang } \\
\text { diberikan didalam } \\
\text { kelas? }\end{array}$ & $\begin{array}{l}\text { Apa saja bentuk } \\
\text { penghargaan yang } \\
\text { diberikan guru di } \\
\text { dalam kelas? }\end{array}$ \\
\hline & $\begin{array}{l}\text { Apa saja bentuk } \\
\text { pemberian } \\
\text { penghargaan yang } \\
\text { digunakan di dalam } \\
\text { kelas? }\end{array}$ & $\begin{array}{l}\text { Bentuk } \\
\text { penghargaan yang } \\
\text { paling disukai } \\
\text { yang diberikan } \\
\text { guru? }\end{array}$ \\
\hline \multirow[t]{3}{*}{$\begin{array}{l}\text { Proses } \\
\text { Pemberian } \\
\text { Penghargaan }\end{array}$} & $\begin{array}{l}\text { Bagaimana } \\
\text { proses pemberian } \\
\text { penghargaan? }\end{array}$ & $\begin{array}{l}\text { Apakah } \\
\text { penghargaan } \\
\text { hanya diberikan } \\
\text { untuk teman- } \\
\text { teman yang } \\
\text { pandai? }\end{array}$ \\
\hline & $\begin{array}{l}\text { Apa saja syarat agar } \\
\text { siswa mendapatkan } \\
\text { penghargaan dari } \\
\text { guru? }\end{array}$ & \multirow{2}{*}{$\begin{array}{l}\text { Apakah } \\
\text { pemberian } \\
\text { penghargaan } \\
\text { selalu diberikan } \\
\text { pada saat } \\
\text { pembelajaran IPS } \\
\text { berlangsung? }\end{array}$} \\
\hline & $\begin{array}{l}\text { Apakah pemberian } \\
\text { penghargaan hanya } \\
\text { berlaku untuk anak } \\
\text { yang pandai? }\end{array}$ & \\
\hline \multirow[t]{4}{*}{$\begin{array}{l}\text { Dampak } \\
\text { Pemberian } \\
\text { Penghargaan }\end{array}$} & $\begin{array}{l}\text { Apa saja dampak } \\
\text { dari pemberian } \\
\text { penghargaan di } \\
\text { dalam kelas? }\end{array}$ & \multirow{4}{*}{$\begin{array}{l}\text { Apakah } \\
\text { penghargaan yang } \\
\text { diberikan guru } \\
\text { membuat siswa } \\
\text { lebih antusias } \\
\text { dalam belajar? }\end{array}$} \\
\hline & $\begin{array}{l}\text { Apakah dengan } \\
\text { pemberian } \\
\text { penghargaan } \\
\text { pembelajaran } \\
\text { menjadi lebih efektif } \\
\text { dan efisien? }\end{array}$ & \\
\hline & $\begin{array}{l}\text { Apakah pemberian } \\
\text { penghargaan selalu } \\
\text { diberikan setiap } \\
\text { pembelajaran IPS } \\
\text { berlangsung? }\end{array}$ & \\
\hline & $\begin{array}{l}\text { Apakah tujuan } \\
\text { dari pemberian } \\
\text { penghargaan di } \\
\text { dalam kelas? }\end{array}$ & \\
\hline
\end{tabular}

Sedangkan kegiatan observasi dalam penelitian ini dilakukan 2 kali. Observasi pertama dilakukan guna mendapatkan informasi sekolah, baik lokasi sekolah, guru yang mengajar dan jumlah siswa yang akan menjadi sumber data penelitian. selanjutnya observasi kedua dilaksanakan pada saat setelah dilakukan wawancara, observasi dilakukan selama 2 minggu agar mendapatkan data yang lebih maksimal.Pengumpulan data dilakukan dengan melihat langsung kegiatan di lapangan dan kegiatan pembelajaran yang dilakukan oleh peserta didik secara terus menerus atau melakukan latihan secara rutin untuk mendapatkan hasil yang diinginkan.

Data yang terkumpul dilihat keabsahannya dengan teknik perpanjangan keikutsertaan, yaitu dengan meningkatkan ketekunan, triangulasi, menggunakan bahan referensi (Moleong, 2002). Teknik analisis data dalam penelitian ini menggunakan model dari Miles dan Huberman. Model tersebut meliputi reduksi data, data display (penyajian data), dan conclusion drawing/verification (kesimpulan/verifikasi) (Sugiyono, 2016).

\section{HASIL DAN PEMBAHASAN}

\section{Hasil Penelitian}

Data yang diperoleh melalui wawancara guru mata pelajaran IPS dan siswa kelas V MIN 1 Lobar, dapat dideskripsikan berikut ini.

\section{Bentuk Penghargaan yang Diberikan oleh Guru dalam Proses Pembelajaran IPS}

Terdapat berbagai macam bentuk penghargaan yang diberikan oleh guru pada siswa. Bentuk penghargaan yang bervariasi sangatlah diperlukan untuk membantu guru dalam menentukan penghargaan untuk tugas yang berbeda. Adapun bentuk-bentuk pemberian penghargaan ada 3 macam, yang pertama pemberian penghargaan dalam bentuk verbal yang terdiri dari pemberian penghargaan dalam bentuk kata "hebat", "bagus", "pintar". Yang kedua pemberian penghargaan dalam bentuk nonverbal berupa yang terdiri dari pemberian senyuman, tepuk tangan, dan acungan jempol. Yang ketiga pemberian penghargaan dalam bentuk barang atau benda yakni dengan pemberian uang, kertas bintang, dan untuk semester terakhir diberikan dalam bentuk buku dan pulpen untuk siswa yang meraih gelar juara 1, 2 dan 3 , dengan harapan siswa yang lain lebih semangat lagi untuk belajar agar bisa mengikuti jejak temannya yang meraih juara.

Pemberian penghargaan dalam bentuk barang 
tidak selalu berupa barang yang mahal ataupun benda-benda mewah, melainkan dapat juga berupa nilai, seperti yang diungkapkan oleh guru mata pelajaran IPS berikut ini:

"Bentuk penghargaan dalam menghargai atau memberi timbal balik tidak selalu berupa barang mahal ataupun benda-benda mewah tetapi juga bisa berupa dalam bentuk pujian atau memberikan nilai. Memang dengan memberikan penghargaan dengan menggunakan barang-barang berharga ataupun dengan menggunakan uang bisa lebih berdampak signifikan pada antusias belajar siswa, tetapi harus diseimbangi dengan kemampuan guru itu sendiri. Pemberian penghargaan tidak hanya berbentuk materi saja, penghargaan juga bisa berupa pujian ataupun diberikan tanda bintang misalnya guru melakukan pemberian penghargaan berupa materi, itu jangan terlalu sering karena yang ditakutkan, siswa akan bersifat matrealistis sehingga akan berdampak pada tujuan pembelajaran yang sebenarnya".

Dari beberapa bentuk penghargaan yang bervariasi yang diberikan oleh guru, nilai merupakan bentuk penghargaan yang paling disenangi oleh siswa. Hal ini disebabkan karena mereka merasa bahwa nilai yang diberikan guru akan menentukan nilai dari akhir semester, dan mereka akan lebih senang jika di akhir semester nilai mereka tinggi. Salah satu alasan lainnya adalah dikarenakan mereka memiliki rasa bersaing antar teman dan dengan nilai yang tinggi akan membuat siswa memiliki ranking yang tinggi di kelas.

\section{Proses Pemberian Penghargaan Dalam Proses Pembelajaran IPS}

Proses pemberian penghargaan yang diberikan oleh guru pada siswa dilakukan pada kegiatan inti pembelajaran. Penghargaan diberikan pada siswa yang mampu menjawab soal yang diberikan oleh guru, dan juga siswa yang mau mencoba menjawab soal yang diberikan oleh guru walaupun jawabannya masih kurang tepat. Hal ini diungkapkan oleh guru mata pelajaran IPS yang menyatakan bahwa:

"Pemberian penghargaan yang berlangsung dalam proses pembelajaran IPS, pemberian penghargaan tidak hanya diberikan kepada siswa yang mampu menjawab soal saja, tetapi juga diberikan kepada siswa yang menjawab soal namun jawabannya masih kurang tepat, hal itu dikarenakan adanya penghargaan yang diberikan bagi siswa yang mau menjawab pertanyaan guru walaupun jawabannya masih kurang tepat, penghargaan sangat penting untuk diberikan kepada siswa tersebut karena banyak siswa yang malas berpikir sehingga tidak mau menjawab pertanyaan yang diberikan oleh guru".

Dalam proses pembelajaran terdapat beberapa tahapan, yakni tahap pendahuluan, inti dan penutup. Pada tahap pendahuluan guru IPS membuka mata pelajaran dengan berdo'a dan mengajukan beberapa pertanyaan terkait dengan materi pelajaran yang sudah dipelajari minggu sebelumnya. Pada tahap kegiatan inti guru membagikan buku paket yang terdapat materi pelajaran yang akan dipelajari. Pada tahapan ini bisa dilihat adanya pemberian penghargaan yang dilakukan oleh guru kepada siswa yaitu guru mengajukan beberapa pertanyaan yang akan dijawab oleh siswa. Pemberian penghargaan dilakukan oleh guru kepada siswa beberapa kali dalam bentuk acungan jempol. Cara lain pemberian penghargaan yang terlihat dalam kegiatan inti adalah dengan cara guru memberikan tepuk tangan kepada siswa yang bisa menjawab pertanyaan yang diberikan oleh guru. Cara pemberian penghargaan yang paling menarik perhatian siswa adalah pada saat penghargaan yang diberikan dalam bentuk hadiah uang. Uang yang diberikan hanya berjumlah dua ribu lima ratus rupiah untuk satu siswa yang bisa menjawab pertanyaan guru. Tingkat kesulitan pertanyaan yang diberikan hadiah uang lebih tinggi dari yang penghargaannya diberikan acungan jempol dan permen saja. Guru juga memberikan tepuk tangan secara bersama-sama dengan siswa untuk siswa yang bersedia mencoba menjawab pertanyaan guru walaupun jawabannya masih kurang tepat. Dalam hal ini Nampak terlihat jelas antusias semangat belajar siswa begitu tinggi, dari yang malas menjawab pertanyaan guru menjadi lebih semangat untuk ikut menjawab pertanyaanpertanyaan yang diajukan oleh guru.

\section{Dampak Pemberian Penghargaan Dalam Proses Pembelajaran IPS}

Pemberian penghargaan yang dilakukan oleh guru mata pelajaran IPS kelas $\mathrm{V}$ pada siswa memberikan dampak terhadap proses belajar siswa. Hal ini ditemukan pada saat observasi pada proses belajar siswa yang berjalan dengan lancar. Dari semula yang proses belajarnya menghabiskan waktu melebihi jam pelajaran dan tujuan pembelajaran tidak tercapai secara penuh, berikutnya menjadi lebih efektif dan efisien. Pemberian penghargaan berdampak pada motivasi belajar anak yang muncul setelah mendapatkan penghargaan dari guru karena siswa merasa dihargai dan diakui hasil pekerjaan atau tindakan yang telah dilakukan. Pemberian penghargaan juga berdampak pada perkembangan kemampuan yang dimiliki oleh siswa karena 
penghargaan akan membantu siswa memahami kemampuan yang dimilikinya. Selain itu, penghargaan juga berdampak pada ikatan emosional siswa dengan guru, sehingga guru akan lebih mudah mengarahkan siswa dan apa yang disampaikan kepada anak akan mudah dipahami. Hal ini seperti yang diungkapkan oleh guru mata pelajaran IPS berikut ini:

"Dengan pemberian penghargaan kepada siswa akan berdampak pada meningkatnya minat belajar siswa yang dapat dilihat dari semangat belajar siswa, mengerjakan soal, aktif dalam setiap proses pembelajaran, jika siswa tersebut belum mengerti tentang materi yang disampaikan guru, siswa akan sangat aktif bertanya terkait materi-materi yang belum dimengerti, dengan meningkatnya antusias belajar siswa maka akan mempengaruhi hasil belajar dari siswa, dikarenakan siswa lebih giat belajar dan juga aktif dalam proses pembelajaran".

Pemberian penghargaan dalam proses pembelajaran memang sangat penting dilakukan oleh guru pada setiap peserta didik. Pemberian penghargaan bisa diberikan dalam bentuk tepuk tangan, acungan jempol, pujian ataupun hadiah. Pada pembelajaran IPS khususnya, adanya pemberian penghargaan sangat penting dilakukan karena pembelajaran IPS identik dengan sejarah dan seperti yang kita ketahui bahwa sejarah itu sangat membosankan sehingga akan membuat siswa kurang semangat belajar. Oleh karena itu pemberian penghargaan sangat diperlukan untuk meningkatkan semangat belajar siswa sehingga akan berdampak pada proses pembelajaran. Dengan adanya pemberian penghargaan yang dilakukan oleh guru pada siswa diharapkan dapat meningkatkan minat belajar siswa, baik dari segi semangat belajar, fokus belajar, antusias dalam menjawab pertanyaan, aktif bertanya jika ada materi yang belum dipahami.

Pemberian penghargaan yang diberikan oleh guru, tidak hanya diberikan kepada siswa yang pandai, yang mampu menjawab soal. Penghargaan juga diberikan kepada siswa yang mau mencoba menjawab soal yang diberikan. Hal ini dilakukan agar semangat belajar siswa tetap terjaga, antusias belajar siswa juga bertahan dan bahkan meningkat. Jika penghargaan hanya diberikan kepada siswa yang mampu menjawab soal-soal yang diberikan oleh guru, itu berarti guru telah mengabaikan keberadaan dari keseluruhan siswa dan tidak mengetahui bahwa siswa memiliki karakter dan kemampuan yang berbedabeda. Seperti yang diungkapkan oleh guru mata pelajaran IPS:

"Pemberian penghargaan tidak hanya diberikan pada siswa yang pandai ataupun yang mampu menjawab pertanyaan yang diberikan oleh guru, tetapi penghargaan juga diberikan pada siswa yang mau mencoba menjawab pertanyaan guru, yang dilihat adalah usahanya, hal itu dilakukan agar percaya diri dari siswa tetap terjaga, siswa tersebut antusias belajarnya lebih meningkat dan tentunya akan membangun motivasi belajar siswa"

Selain pemberian penghargaan diberikan pada siswa untuk meningkatkan antusias belajar siswa dan meningkatkan keaktifan siswa dalam proses pembelajaran yang berlangsung, pemberian penghargaan juga dilakukan agar siswa tetap merasa senang tidak merasa dibebani oleh materi pelajaran. Hal ini senada dengan yang diungkapkan oleh guru mata pelajaran IPS, yang mengungkapkan bahwa:

"Pemberian penghargaan juga bertujuan agar siswa ketika mengikuti proses pembelajaran yang berlangsung tetap merasa senang, tidak merasa bosan ataupun lelah dengan materi-materi yang disampaikan oleh guru"

Pemberian penghargaan dalam proses belajar mengajar pada dasarnya bertujuan agar siswa mendapatkan penghargaan atau timbal balik dari guru setelah melakukan suatu kegiatan belajar dengan baik. Selain itu pemberian penghargaan juga dilakukan agar siswa ketika proses pembelajaran berlangsung tetap merasa senang, tidak merasa dibebani dengan materi-materi yang disampaikan oleh guru. Ada rasa kepuasaan dan kebahagiaan tersendiri yang dirasakan oleh guru ketika melihat siswa di dalam proses pembelajaran yang berlangsung, tetap terlihat senang.

\section{Pembahasan}

\section{Bentuk Penghargaan yang Diberikan oleh Guru dalam Proses Pembelajaran IPS}

Bentuk-bentuk penghargaan yang diberikan oleh guru pada siswa berupa pemberian acungan jempol, hadiah dalam bentuk uang, penghargaan dalam bentuk barang seperti permen, bolpoin, pensil, buku atau pun alat tulis lainnya. Pemberian penghargaan juga bisa dilakukan dalam bentuk pemberian katakata yang siswa senang mendengarnya seperti kata "bagus", "baik", "hebat", "pintar", penghargaan dalam bentuk nilai dan berupa tepuk tangan". Hal ini sejalan dengan pendapatnya Zeeno dalam Rusdiana (2006) tentang jenis-jenis pemberian penghargaan, diantaranya adalah: 1) Pujian yang mendidik; 2) Memberi hadiah; 3) Mendo'akan; 4) Papan prestasi; 5) Menepuk pundak, 6) Menjadikan acuan pada siswa yang berprestasi dalam memberikan semangat siswa 
yang lain; 7) Berpesan pada yang lain; 8) Berpesan pada keluarga siswa yang bersangkutan.

Dengan adanya berbagai macam jenis pemberian penghargaan yang diberikan kepada siswa oleh guru, maka akan menghilangkan rasa jenuh dari siswa terhadap pemberian penghargaan yang sama. Ketika pemberian penghargaan hanya dilakukan dengan satu jenis penghargaan, contohnya hanya menggunakan penghargaan dalam bentuk acungan jempol saja, tidak bisa kita pungkiri siswa akan merasa bosan ataupun jenuh dengan penghargaan tersebut. Setiap hari penghargaan yang diterima oleh siswa ketika mampu menjawab soal hanya monoton seperti itu saja secara berturut-turut tidak ada variasinya, maka akan membuat siswa kurang bersemangat dalam proses pembelajaran, karena siswa sudah tahu penghargaan yang akan didapatkan akan sama seperti waktu sebelumnya. Siswa lebih senang jika penghargaan yang diberikan oleh guru tidak sama dengan waktu yang sebelumnya. Apalagi jikalau dalam dua pertanyaan yang berturut-turut satu siswa yang mampu menjawab dengan tepat namun penghargaan yang didapatkan oleh siswa tersebut tetap dalam bentuk kata "pintar" saja, maka guru bisa juga menggunakan kata "hebat" supaya kesannya penghargaan yang didapatkan oleh siswa dari guru menjadi bertingkat.

Bentuk-bentuk penghargaan yang digunakan oleh guru mata pelajaran IPS kelas V MIN 1 Lobar ada berbagai macam, seperti acungan jempol, uang dan barang misalnya seperti permen, bolpoin, pensil, buku ataupun alat tulis lainnya. Pemberian penghargaan juga bisa dilakukan dalam bentuk pemberian katakata yang siswa senang mendengarnya seperti kata "bagus", "baik", "hebat", "pintar". Selain itu pemberian penghargaan dalam bentuk nilai dan tepuk tangan. Bentuk penghargaan yang paling disenangi oleh siswa adalah penghargaan yang berupa pemberian nilai atau angka. Hal ini diperkuat oleh hasil peneletian terdahulu yang dilakukan oleh Ikranagara (2015) bahwa partisipan memberikan penghargaan dalam bentuk verbal yakni pujian dan barang pada dua siklus yang berbeda.

\section{Proses Pemberian Penghargaan Dalam Proses Pembelajaran IPS}

Proses pemberian penghargaan yang dilakukan oleh guru pada mata pelajaran IPS kelas V dilakukan dengan menggunakan berbagai jenis penghargaan. Penghargaan diberikan pada siswa dilakukan sesering mungkin namun tidak terkesan berlebihan. Pemberian penghargaan tidak hanya menggunakan satu jenis penghargaan dan dilakukan tidak hanya satu kali dalam satu pertemuan namun di dalam satu pertemuan tersebut pemberian penghargaan dilakukan lebih dari satu kali sesuai dengan kebutuhan siswa yang nampak pada kegiatan inti dalam proses pembelajaran. Pemberian penghargaan yang dilakukan oleh guru tidak hanya diberikan pada siswa yang mampu menjawab pertanyaan dari guru tetapi juga diberikan kepada siswa yang mau mengangkat tangan dan mencoba untuk menjawab pertanyaan yang diberikan oleh guru.

Pemberian penghargaan dilakukan sesering mungkin sesuai dengan kondisi kelas tetapi tidak terlalu sering yang akan memakan waktu proses pembelajaran. Pemberian penghargaan kepada siswa tidak hanya dilakukan satu kali dalam 1 kali pertemuan namun dilakukan tergantung kebutuhan dari siswa itu sendiri. Jika memang pada saat itu siswa butuh diberikan penghargaan dikarenakan mampu menjawab pertanyaan guru ataupun mau mencoba menjawab pertanyaan yang diajukan oleh guru, maka pada saat itu juga guru memberikan penghargaan pada siswa. Pemberian penghargaan tidak hanya diberikan kepada siswa yang bisa menjawab soal saja namun juga diberikan kepada siswa yang mau mencoba untuk menjawab, namun bentuk penghargaan-nya yang berbeda. Misalnya, seperti saat ada siswa yang mampu menjawab soal diberikan hadiah dalam bentuk barang seperti uang, namun siswa yang mau mencoba menjawab pertanyaan guru tetapi jawabannya masih kurang tepat diberikan penghargaan berupa acungan jempol saja.

Hal tersebut sejalan dengan pendapat Hasibuan \& Moedjiono (2012), bahwa pemberian penghargaan kepada siswa yang tidak mampu menjawab soal dengan tepat dilakukan agar siswa lebih berusaha lagi dalam proses pembelajaran yang berikutnya. Penghargaan mempunyai pengaruh positif dalam kehidupan manusia sehari-hari, yaitu mendorong seseorang memperbaiki tingkah laku serta meningkatkan kegiatan atau usahanya.

Pada saat memberikan penghargaan dalam bentuk materi seperti uang harus tetap memperhatikan kemampuan guru tersebut sehingga penghargaan yang diberikan kepada siswa tidak akan membebani guru. Tidak masalah jikalau memberikan siswa penghargaan dalam bentuk uang namun harus tetap memperhatikan tujuan dari pemberian penghargaan itu sendiri. Pada umumnya pemberian penghargaan dilakukan agar siswa lebih antusias belajarnya pada setiap proses pembelajran yang akan mempengaruhi hasil belajar dari siswa itu sendiri. Jika pemberian penghargaan terlalu sering dilakukan walaupun dari 
pihak guru tidak merasa dibebani dengan hal tersebut namun akan memengaruhi tujuan dari pemberian penghargaan. Dengan pemberian uang yang terlalu sering akan menimbulkan jiwa materialistis pada siswa sehingga siswa akan melakukan tugastugas yang diberikan guru dengan baik dan akan menjawab soal dengan tepat karena mengharapkan pemberian penghargaan yang bersifat materi seperti uang. Sehingga makna dari pembelajaran yang telah dilakukan oleh siswa menjadi berubah dan tidak akan lagi belajar karena memang siswa menginginkan untuk mendapatkan hasil belajar yang meningkat.

Guru dalam memberikan penghargaan sangat memperhatikan bagaimana pemberian penghargaan tersebut harus diberikan kepada siswa, seperti ketika saat memberikan penghargaan guru sangat bersemangat menunjukkan atau menampakkan bentuk penghargaan yang digunakan. Saat memberikan tepuk tangan, guru melakukannya dengan kencang ataupun meriah. Saat memberikan pujian dalam bentuk kata "bagus", "tepat" dengan nada suara yang bersemangat. Jika pada saat guru memberikan penghargaan tidak ada semangat atau antusiasme, maka siswa akan merasa bahwa penghargaan yang diterima dari guru tersebut tidak begitu membanggakan. Karena tidak nampak antusiasme dari guru itu sendiri, maka kesan yang diterima oleh siswa adalah bahwa pekerjaan yang telah dilakukannya tidak membanggakan.

Terdapat unsur positif dalam pemberian penghargaan yang dilakukan oleh guru pada siswa. Ketika guru memberikan penghargaan menggunakan respon yang positif dengan kata-kata yang menyemangati seperti kata "bagus", "baik", maupun acungan jempol, tujuannya adalah untuk membangun ataupun menyemangati siswa sehingga akan membuat semangat dan fokus belajar siswa semakin meningkat, dan juga siswa semakin aktif dalam proses pembelajaran. Hadiah-hadiah yang diberikan oleh guru ini juga dimaksudkan agar penghargaan yang diberikan bersifat lebih bermakna. Hal ini memperkuat teori yang mengungkapkan bahwa penghargaan diberikan oleh guru dengan memberikan hadiah atas hal positif yang dilakukan oleh siswa.

Pemberian penghargaan yang dilakukan oleh guru pada siswa dilakukan dengan cara pribadi dan berkelompok, misalnya ketika memberikan penghargaan dalam bentuk acungan jempol dilakukan secara pribadi. Penghargaan yang bersifat pribadi lainnya yang dilakukan oleh guru pada siswa juga berupa penghargaan dalam bentuk kata "hebat", "baik", dan juga memberikan penghargaan dalam bentuk memberikan barang seperti pulpen, pengahapus dan alat tulis lainnya. Sedangkan ketika memberikan penghargaan dengan cara berkelompok dilakukan dengan cara memberikan penghargaan dalam bentuk tepuk tangan yang meriah bersamasama dengan semua siswa. Cara-cara pemberian penghargaan yang dilakukan oleh guru pada siswa ini sesuai dengan teori yang ada terkait tentang prinsip-prinsip penggunaan penghargaan, sebagai berikut: (1) penuh kehangatan dan keantusiasan, yaitu memberikan penghargaan secara hangat dan antusias agar siswa yang mendapatkan penghargaan tersebut lebih bersemangat dalam setiap kegiatan proses pembelajaran. (2) menghindari penggunaan respons negatif, yaitu memberikan penghargaan dengan cara yang positif, tindakan yang positif, kalimat-kalimat yang positif, tidak dengan cara mengeluarkan kalimat yang menjatuhkan ataupun merendahkan. (3) bermakna bagi siswa, yaitu pemberian penghargaan dalam hal membangun atau memotivasi agar siswa yang mendapatkan penghargaan tersebut merasa bahwa hal yang dilakukan merupakan hal yang membanggakan. (4) dapat bersifat pribadi atau kelompok, yaitu penggunaan penghargaan yang dilakukan bisa berupa pribadi ataupun kelompok, tidak hanya berupa pribadi saja ataupun kelompok saja.

\section{Dampak Pemberian Penghargaan Dalam Proses Pembelajaran IPS}

Pemberian penghargaan dalam proses pembelajaran merupakan suatu bentuk penghargaan yang dilakukan oleh guru pada siswa sebagai bentuk timbal balik terhadap suatu kegiatan yang dilakukan siswa agar siswa tersebut dapat meningkat minat belajarnya. Tujuan dari pemberian penghargaan ini adalah supaya dalam proses pembelajaran siswa yang telah diberikan penghargaan menjadi lebih aktif lagi dalam kegiatan pembelajaran misalnya seperti, lebih aktif bertanya ketika ada materi yang belum dipahami, lebih antusias mendengarkan penjelasan dari guru terkait materi, dan lebih giat belajar. Hal ini diperkuat dengan teori yang menungkapkan bahwa pemberian penghargaan dimaksudkan untuk membuat anak lebih giat lagi usahanya untuk bekerja dan berbuat lebih baik lagi.

Dengan adanya perubahan-perubahan perilaku yang terjadi pada siswa dalam proses pembelajaran seperti yang telah disebutkan, maka hal tersebut akan membantu siswa dalam meningkatkan hasil belajarnya. Pemberian penghargaan yang dilakukan oleh guru terhadap siswa bertujuan untuk meningkatkan antusiasme belajar siswa. Dengan 
meningkatnya antusisasme belajar siswa maka akan memengaruhi tingkat perhatian siswa dalam mendengarkan ataupun memahami materi yang disampaikan oleh guru, membangun semangat dan mempertahankan motivasi belajar siswa. Motivasi belajar siswa pada awal pembelajaran masih nampak namun setelah beberapa menit kemudian motivasi belajar siswa tetap harus dipertahankan. Dengan adanya pemberian penghargaan kepada siswa, siswa lebih bersikap baik terhadapa guru dikarenakan nampak penghargaan yang diberikan kepada siswa sehingga siswa merasa lebih dihargai, siswa lebih aktif dalam proses pembelajaran, siswa lebih berusaha untuk mengembangkan kemampuan yang dimiliki. Dengan tercapainya beberapa tujuan dari adanya pemberian penghargaan akan membantu kelancaran dari proses pembelajaran. Hal ini diperkuat dengan teori yang mengungkapkan tentang tujuan dari adanya pemberian penghargaan. Menurut Hamid (2006), tujuan pemberian penghargaan kepada anak dimaksudkan sebagai penghargaan dan rasa bangga atas pekerjaan dan prestasi anak, sekaligus dengan niat agar anak melakukannya terus menerus meningkatkan semangat dan motivasi serta minatnya dalam bekerja dan belajar. Hal sejalan juga diungkapkan oleh Purwanto dalam Ernata (2017), tujuan dari pemberian penghargaan adalah untuk memberikan motivasi kepada peserta didik, agar dapat melakukan perbuatan terpuji dan berusaha untuk meningkatkannya.

\section{PENUTUP}

\section{Simpulan dan Saran}

Berdasarkan paparan data temuan dan pembahasan, dapat disimpulkan bahwa dampak pemberian penghargaan dalam proses pembelajaran IPS pada siswa kelas V MIN 1 Lobar adalah meningkatnya perhatian dan keaktifan siswa dalam proses pembelajaran, meningkatkan antusiasme belajar siswa, dan siswa lebih bisa dikendalikan tingkah lakunya ketika proses pembelajaran berlangsung. Terdapat beberapa saran yang perlu mendapat perhatian dari semua pihak yang berkepentingan mengenai pemberian penghargaan pada pembelajaran IPS di antaranya: 1) bagi kepala sekolah, hendaknya lebih meningkatkan apresiasinya kepada siswa, baik kepada siswa yang berprestasi pada bidang akademik maupun non akademik, 2) bagi guru, hendaknya lebih meningkatkan pemberian penghargaan kepada siswa sehingga proses pembelajaran yang berlangsung berjalan dengan kondusif, 3) bagi siswa, diharapkan dengan adanya pemberian penghargaan siswa lebih antusias, lebih aktif, lebih fokus dalam mengikuti proses pembelajaran agar tujuan dari pembelajaran bisa tercapai sesuai dengan tujuan pembelajaran yang sudah ditetapkan, 4) penulis berharap ada penelitian lagi yang mengangkat permasalahan ini agar penelitian ini menjadi lebih sempurna dan diharapkan dapat menambah wawasan bagi kita semua mengenai pemberian penghargaan pada pembelajaran IPS.

\section{DAFTAR PUSTAKA}

Danim, S. (2002). Menjadi Peneliti Kualitatif Rancangan Metodologi, Presentasi, dan Publikasi Hasil Penelitian Untuk Mahasiswa dan Penelitian Pemula Bidang Ilmu Sosial, Pendidikan, dan Humaniora. Bandung: Romaja Rosdakarya.

Ernata, Y. (2017). Analisis Motivasi Belajar Peserta Didik melalui Pemberian Reward dan Punishment di SDN Ngaringan 05 Kec.Gandusari Kab.Blitar. Jurnal Pemikiran dan Pengembangan SD, 5, (2), 781-790. DOI: 10.22219/jp2sd.v5i2.4828

Febianti, Y.N. (2018). Peningkatan Motivasi Belajar dengan Pemberian Reward and Punishment yang Positif. Jurnal Edunomic, 6 (2), 93-102. DOI: 10.33603/ejpe.v6i2.1445

Hamalik, O. (2012). Psikologi Belajar dan Mengajar. Bandung: Sinar Baru Algensindo.

Hamid, R. (2006). Reward dan Punishment dalam Perspektif, Ittihad Jurnal Kopertis Wilayah XI Kalimantan, 4 (5), 65-77. Retrieved from https:/ / www.academia.edu/1339973/ REWARD_DAN_PUNISHMENT_DALAM_ PERSPEKTIF_PENDIDIKAN_ISLAM

Huliyah, M. (2016). Hakikat Pendidikan Anak Usia Dini, As-Sibyan: Jurnal Pendidikan Guru Raudlatul Athfal, 1 (1), 60-71. Retrieved from http://jurnal.uinbanten.ac.id/index.php/ assibyan / article/view/193/195

Ikranagara, P. (2015). Pemberian Reward dan Punishment untuk Meningkatkan Kedisiplinan Siswa dalam Pembelajaran IPS Kelas V SD Negeri 1 Kejobong Purbalingga, Basic Education, 2 (4). Retrieved from http:/ /journal. student.uny.ac.id/ojs/index.php/pgsd/ article/ view/426

Moleong, L. (2002). Metodologi Penelitian Kualitatif. Bandung: Remaja Rosdakarya.

Sugiyono. (2016). Metode Penelitian Kuantitatif, Kualitatif, dan RED. Bandung: Alfabeta.

Susanto, A. (2014). Teori Belajar dan Pembelajaran di Sekolah Dasar. Jakarta: Kencana. 